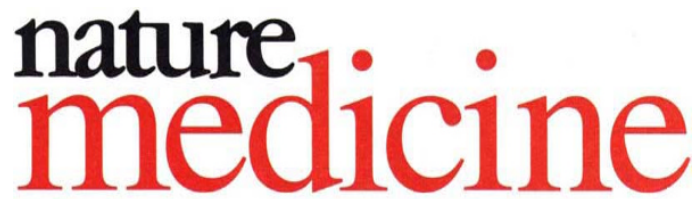

VOLUME 3 • NUMBER $10 \bullet$ OCTOBER 1997

\title{
Wrong kind of chemokine research
}

Within the HIV research community, a few discoveries have had a disproportionate influence, monopolizing the interest and resources of many. The discovery of a dramatic and eventually exhausting viral and $\mathrm{T}$-cell dynamic did it, as did triple therapy. Now it is the turn of chemokines and their receptors, a group of 7-transmembrane receptors involved in HIV infection. Although this is one of the few fashions that is certainly worth following, researchers must keep their eye on the ball.

Following the discovery that a mutation in one of these receptors, CCR5, can render a cell resistant to infection, there was a rush to find out how many in the high risk, but infection free, community were homozygous for the mutated allele. The 32 base pair mutation fell within the coding region and gave rise to a non-functional protein, thus there was good reason to believe that heterozygotes would also benefit. With HIV's near universal reputation for dodging all attempts to kill it, here at last was a dodge of our own and a tremendous effort went into establishing the epidemiology of the mutation and its impact.

Although none is known to be so crucial to HIV entry as CCR5, attention also turned to other chemokine receptors and in August Stephen O'Brien and colleagues from the N.C.I. announced in Science that a mutation in the minor coreceptor CCR2 influenced disease progression, although no effect on incidence was found. The mutation (CCR2-641) was found at allele frequencies of up to $15 \%$, suggesting any effect could be widespread. However, this finding was less satisfying than the CCR5 observation: Although the mutation affects the coding region, it is a single base change resulting in a conservative valine to isoleucine substitution and as the authors noted, "the mechanism ... is not immediately apparent." It is also difficult to imagine why the disease progression effect would be found in the absence of a transmission effect. Nonetheless, the data were there: HIV-1 infected individuals carrying the mutated allele progressed to AIDS 2-4 years later than those without it; and immediately many groups started testing their cohorts.

On page 1160 of this issue, Nelson Michael and colleagues report their CCR2641 results. They confirm the absence of an association between CCR2-641 and transmission, but they also find no association with disease progression. So what went wrong? Michael et al. studied a far smaller cohort - perhaps too small to pick up a modest effect. Then again, perhaps there is no effect. In a letter to the editor on page 1052, O'Brien et al. (who were aware of the Michael et al. study at the time of submission) argue that by virtue of an inappropriate cohort and study design, Michael et al. have simply missed the effect. Although this seems unlikely, time will tell.

Unfortunately, it will take a lot of time and a great deal of effort. Many groups will now be studying their own cohorts, turning over resources to study what is, in the grander scheme of things, a relatively trivial issue. Far better to establish a central database and sample repository such that all future leads of this sort will be studied once, thoroughly and definitively. It is a pity that the HIV community does not seem well suited to this level of cooperation. As Science summarized recently, and Paolo Lusso discusses in a News \& Views on page 1074 of this issue, there are much more pressing and potentially important aspects of chemokine biology to be addressed. Perhaps Michael et al.'s article will make the CCR2-641 issue less pressing.

\section{Next year's Nobels?}

The Albert Lasker Medical Research Awards were established in 1946 to celebrate scientists, physicians and public servants whose accomplishments have had a major impact on the treatment or understanding of disease. Nature Medicine is delighted to be publishing commentaries penned by the three 1997 winners.

The Basic Medical Research Award goes to the renowned gene regulation expert Mark Ptashne, who has doggedly sought to understand the fundamental mechanisms that activate and inactivate genes (see page 1069). The Clinical Medical Research Award honors Alfred Sommer, whose persistence eventually convinced a far too skeptical medical community that vitamin A supplements could save the sight and lives of thousands of children worldwide (see page 1061). And the Special Achievement in Medical Science Award is given to Victor McKusick, "The Father of Medical Genetics", for an unparalleled contribution to gene mapping and the human genome project (see page 1065).

Many consider the Lasker Awards the country's most prestigious. So where do you go when you are at the top? A little higher, apparently. The Lasker Foundation is very proud of the fact that its awards regularly prophesy the Nobels. In fact, since 1946, fifty six of the Lasker winners have gone on to win Nobels - perhaps this years Lasker winners should plan to vacation in Sweden next year. 